\title{
BARRIERS TO THE INNOVATION OF THE FOOD INDUSTRY IN THE EUROPEAN UNION MEMBER COUNTRIES
}

\author{
BARIERY INNOWACYJNOŚCI PRZEMYSŁU SPOŻYWCZEGO \\ W KRAJACH CZŁONKOWSKICH UNII EUROPEJSKIEJ
}

https://doi.org/10.34739/zn.2019.49.03

Katarzyna Łukiewska

Poland, University of Warmia and Mazury in Olsztyn, Faculty of Economic Sciences ORCID: 0000-0002-3175-5495, e-mail: katarzyna.lukiewska@uwm.edu.pl

\begin{abstract}
In conditions of increased competition, development of biotechnology and the ever growing demands of the consumers, innovations are becoming an important factor of competitiveness in the food industry. The aim of the conducted research was to evaluate the barriers of innovativeness in the food industry based on chosen European Union countries during 2014-2016. Based on research of CIS-2016 carried out in accordance with the Oslo methodology developed by OECD, the barriers of innovativeness within the food industry enterprises which were active and non-active were analyzed. As for the evaluation of the analyzed factors within the countries of the EU, descriptive statistics and Ward's method, which is an agglomeration form of grouping method, were used. From the conducted research, it followed, that the representations of innovative active enterprises more often reported on the barriers which were impeding the introduction of innovations. The most common which were reported included big competition, lack of internal funding and high costs. Representatives of inactive innovative enterprises were reporting low demand on the market, lack of internal funding and high costs.

Keywords: food industry, innovation, barrier, Ward's method, European Union
\end{abstract}

\begin{abstract}
Streszczenie: W warunkach wzrostu konkurencji, rozwoju biotechnologii i coraz większych wymagań konsumentów innowacje stają się ważnym czynnikiem konkurencyjności w przemyśle spożywczym. Celem przeprowadzonych badań była ocena barier innowacyjności przemysłu spożywczego na przykładzie wybranych krajów Unii Europejskiej w latach 2014-2016. Na podstawie badań CIS-2016 opartych na metodologii Oslo opracowanej przez OECD przeanalizowano postrzeganie barier innowacyjności w przedsiębiorstwach przemysłu spożywczego aktywnych i nieaktywnych innowacyjnie. Do oceny znaczenia analizowanych czynników w poszczególnych krajach członkowskich UE wykorzystano statystyki opisowe oraz metodę Warda należącą do aglomeracyjnych metod grupowania. Z badań wynika, że reprezentanci przedsiębiorstw aktywnych innowacyjnie częściej zgłaszali występowanie czynników utrudniających wdrażanie nowości. Do najczęściej wskazywanych przez nich wysoce istotnych barier innowacji należały: wysoka konkurencja, brak wewnętrznego finansowania i wysokie koszty. Reprezentanci przedsiębiorstw nieaktywnych innowacyjnie powszechnie wskazywali natomiast: niski popyt na rynku, brak wewnętrznego finansowania i wysokie koszty.
\end{abstract}

Słowa kluczowe: przemysł spożywczy, innowacje, bariery, metoda Warda, Unia Europejska

\section{Introduction}

Innovativeness is one of the key factors of the competitiveness of enterprises and branches (Lewandowska, 2014; Toth, Ferto, 2017). Important branches of the economy in the EU in economic and social terms is the food industry. It consists of around 264 thousand enterprises in which there are about 4,3 million people employed which is $14 \%$ of all employed people in the food industry sector. The yearly value of production sold is about 914 billion euro (Eurostat, 2019). It also participates in the fulfilment process of basic human needs and ensures food security (Gardijan, Lukač, 2018, Wilson, 2018).

The food industry, according to the classification proposed by OECD was included in the sectors of low technology (Hatzichronoglou, 1997). It means that the level of innovativeness of enterprises producing food may be lower than in other branches of the industrial process. However, Fortuin, Omta (2009, p. 839) highlight that globalization, the need to ensure food safety, nutritional quality and consumer demand for convenience, diversity, quality and new opportunities created by the biotechnology revolution have led to the fact that the industry has become 
more focused on creating products that meet the requirements of consumers. In the creation of food products adjusted to the needs of the clients, innovations play a crucial part. They may be a peculiar lever to meet consumer-citizen's needs (Mancini et al., 2015). Due to this fact it is relevant to define the real conditions of the introduction of new solutions by food producers.

In literature of the subject there are many factors which are shaping the innovative actions of enterprises. They are mostly divided into internal and external factors. Among the internal factors there are: economical factors (the level of economic development of the country, realization of innovative policy, funding of innovations, science, research and growth), socio-cultural factors (use, dissemination and development of innovation over time), legal factors (enabling the innovative growth of enterprises connected with conduction of research-development actions and financial support of innovations) and technological factors (development of techniques and technologies) (Dolińska, 2010). Attention is also paid to the competition on the market, upward/ downward trend on the market, branch synergy and others (Szopik-Depczyńska, 2009). As for the internal factors there are such elements as: personal expenditure on $R+D$ works, expenditure on innovations, the number and qualifications of the staff, motivational system, abilities and research experience, laboratories and their equipment, production and marketing factors, effectiveness of information systems, elements of communications and motivation in enterprises, innovations strategy development, relations with partners and organizational culture (Kolarz, 2006; Dolińska 2010; Strychalska-Rudzewicz, 2012).

Empirical identification of factors which are restricting the innovativeness may help in conducting the broadly understood, purposeful and effective activity supporting the functioning and competitiveness of subjects which are producing food articles and the development of the food market in the EU. Rudawska (2017) also highlights that systematic verifications of barriers presented in literature is necessary, because the external surroundings and organizational context are in so much change that this may introduce new barriers and some of the old may be vanishing, while others

\footnotetext{
${ }^{1}$ The arithmetic mean is the most common measure of locations and indicates the average (typical) level of a variable. Lower quartile (first) is the value of the unit which divides the community in such a way, that $25 \%$ of the units have not higher values and $75 \%$ not less. Median is the value of unit located in the community in a way that divides the community into two equal parts. Upper quartile (third) is a value of unit which divides the community in a
}

may be still felt. In this context, the aim of the research was to evaluate the innovativeness barriers of the food industry based on chosen European Union countries during 2014-2016.

\section{Materials and methods}

The international methodology of defining, classification and measurement of innovations developed by the Organization for Economic Co-operation and Development (OECD) contained in the Oslo Manual Guidelines for collection and interpreting innovation data was used in this study. According to the definition proposed by OECD innovation is: "the implementation of a new or significantly improved product (good or service), or process, a new marketing method, or a new organisational method in business practices, workplace organisation or external relations" (Oslo Manual 2005, p. 46). Source of the data on barriers of innovations implementation was the international programme Community Innovation Survey (CIS) initiated in the beginning of the 90s of XX century by the European Commission, whose results are regularly published in Eurostat.

Methodology contained within them is based on the Oslo Guidelines. In elaboration the most actual data from CIS-2016 covering its scope and range of innovativeness of enterprises during 2014-2016, were used. Adopted for analysis, the EU countries were implemented for which there was statistical data about the barriers of innovativeness within the food industry sector. In accordance with OECD recommendations (Oslo Manual 2005), both factors hampering the conduct of innovative activity in innovation-active enterprises and barriers to innovation in innovation-inactive enterprises were analyzed. Evaluation of the importance of analyzed factors and barriers was carried out using comparative method of answers within the chosen countries of the EU which were: arithmetic mean, coefficient of variation as well as the median $(\mathrm{Me})$, lower (Q1) and upper quartile (Q3) of distribution of indicators which are presented in the box plots ${ }^{1}$.

Next, on the basis of Ward's method the analyzed countries were grouped by the similarities of evaluation of chosen factors hindering and innovativeness barriers. This method belongs to

way that $75 \%$ units have values not greater than it and $25 \%$ not less. The coefficient of variation determines how much the group of observation is varied with respect to a certain feature. It was calculated according to the formula: $V_{j}=\frac{S_{j}}{\bar{x}_{j}}$, where: $S_{j}$ - standard deviation of the characteristics $j, \bar{x}_{j}$ - arithmetic mean of the characteristics j (Stanisz, 2006). 
a group of hierarchical agglomeration methods of cluster analysis. Its essence depends on extraction from the set of objects (EU countries), homogenous subsets to be as similar as possible in the range of a group, and objects belonging to different classes were as different as possible. Using the Ward method at the beginning it is assumed that each object (country) is a separate group. Then step by step the most similar objects are gradually joined into subgroups. As a measurement of distance between the examined objects the Euclidean distance was accepted, which shows the real geometric distance in multidimensional space (Suchecki, Lewandowska-Gwarda, 2010):

$d_{i j}=\left[\sum_{k=1}^{m}\left(z_{i k}-z_{j k}\right)^{2}\right]^{1 / 2}$

where: $d_{i j}$ - distance between two considered objects, $z_{i k}, z_{j k}$ - values of normalized variable for objects $\mathrm{i}$ and $\mathrm{j}$.

The groups of objects in accordance to Ward's method were connected in a way to minimize the sum of squares of deviation of those two groups from the middle of heaviness of the new group, which emerged from their connection (Panek, Zwierzchowski, 2013). The merger process was continued until all countries formed one group. The grouping was graphically presented using a hierarchical tree called the dendrogram. Based on it, the number of clusters was selected. The statistical programme STATISTICA was used for the calculations.

\section{Results and discussion}

The process of the creation of innovations is usually complex. Thus, many factors on various stages of implementation of new solutions may impede the conduction of innovative activity. Not all of them affect entrepreneurs with the same intensity and frequency.

Results of the research point out that among enterprises of the food industry in various countries of the EU which were innovative active during 2014-2016, the most indicated factor which was highly impeding the activity of innovative activity was high competition (Table 1). According to the Schumpeter theory, a higher level of competitiveness leads to the reduction of innovations (Soriano et al., 2018). According to Aghion et al. (2005) relations between competition and innovations have an inverted-U shape. Michalski (2014) highlights that strong competition causes the lowering of profits and gives less liberty of conducting the activity.

Table 1. Factors highly hampering innovative activity in innovation-active enterprise in the food industry in selected EU member states in 2014-2016 (\%)

\begin{tabular}{|c|c|c|c|c|c|c|c|c|}
\hline & $\begin{array}{l}\text { Lack of } \\
\text { internal } \\
\text { finance }\end{array}$ & $\begin{array}{l}\text { Lack of external } \\
\text { finance (credit } \\
\text { or private } \\
\text { equity) }\end{array}$ & $\begin{array}{l}\text { High } \\
\text { costs }\end{array}$ & $\begin{array}{c}\text { Lack of } \\
\text { qualified } \\
\text { employees } \\
\text { within } \\
\text { enterprise }\end{array}$ & $\begin{array}{c}\text { Lack of } \\
\text { collaboration } \\
\text { partners }\end{array}$ & $\begin{array}{c}\text { Difficulties } \\
\text { in obtaining } \\
\text { public } \\
\text { grants or } \\
\text { subsidies }\end{array}$ & $\begin{array}{c}\text { Uncertain } \\
\text { market } \\
\text { demand }\end{array}$ & $\begin{array}{c}\text { High } \\
\text { competition }\end{array}$ \\
\hline Bulgaria & 22,3 & 13,0 & 30,0 & 17,2 & 10,6 & 28,4 & 15,6 & 25,5 \\
\hline Germany & 15,4 & 14,9 & 25,2 & 17,6 & 10,7 & 16,8 & 8,9 & 15,3 \\
\hline Estonia & 26,5 & 13,3 & 27,4 & 15 & 3,5 & 12,4 & 12,4 & 24,8 \\
\hline Greece & 40,5 & 33,6 & 33,6 & 22,2 & 9,3 & 41,5 & 26,7 & 32,5 \\
\hline Croatia & 55,8 & 37,4 & 49,6 & 30,2 & 31,3 & 52,7 & 28,7 & 35,1 \\
\hline Italy & 26,3 & 16,1 & 9,7 & 21,0 & 10,0 & 12,9 & 30,1 & 30,8 \\
\hline Cyprus & 45,3 & 36,5 & 47,8 & 28,1 & 14,7 & 36,0 & 22,8 & 59,0 \\
\hline Latvia & 36,0 & 17,5 & 38,8 & 7,1 & 12,0 & 27,0 & 28,8 & 36,0 \\
\hline Hungary & 32,3 & 18,8 & 32,1 & 30,3 & 4,8 & 26,1 & 14,3 & 22,1 \\
\hline Malta & 15,8 & 0,0 & 31,6 & 21,1 & 0,0 & 5,3 & 26,3 & 42,1 \\
\hline Austria & 17,1 & 9,4 & 22,6 & 23,7 & 6,6 & 20,8 & 15,6 & 19,6 \\
\hline Poland & 15,7 & 10,5 & 24,6 & 8,9 & 5,2 & 18,3 & 17,4 & 16,5 \\
\hline Portugal & 27,3 & 18,3 & 31,0 & 19,5 & 11,3 & 28,0 & 16,6 & 38,7 \\
\hline Slovenia & 52,7 & 22,9 & 35,2 & 25,3 & 12,8 & 38,2 & 31,3 & 46,4 \\
\hline Slovakia & 44,8 & 10,3 & 24,1 & 21,4 & 11,0 & 24,1 & 18,6 & 35,2 \\
\hline arithmetic mean & 31,6 & 18,2 & 30,9 & 20,6 & 10,3 & 25,9 & 20,9 & 32,0 \\
\hline $\begin{array}{l}\text { coefficient } \\
\text { of variation (\%) }\end{array}$ & 43,4 & 58,1 & 32,1 & 33,1 & 68,7 & 48,1 & 34,6 & 37,2 \\
\hline
\end{tabular}


This was most often indicated by respondents from Cyprus - 59,0\%, Slovenia - 46,6\%, Malta $42,1 \%$, Portugal $-38,7 \%$ and Latvia $-36,0 \%$. On Cyprus, Malta, in Portugal and Italy high competition was the first factor from the group of the ones which are impeding the innovative activities. In the research carried out by Cetera (2010) entrepreneurs indicated the following forms of financial support for innovation activities: reducing interest rates on loans, shortening the period of depreciation of fixed assets, introducing tax reliefs and subsidies, facilitating access to credit guarantees and procedures for applying for funds for the development of innovation, subsidies for promotional, innovative goals and R\&D activity.

A highly significant obstacle in conducting the innovative activity was lack of internal finance. A high value of arithmetic mean, median and third quartile of response points to it (Figure 1). Such an obstacle in highest degree was felt by enterprises of the food industry from Croatia - 55,8\%, Slovenia - 52,7\%, Cyprus - 45,3\%, Slovakia - 44,8\% and Greece $40,5 \%$. In countries such as Croatia, Slovenia, Romania, Slovakia as well with France and Hungary, this was the mostly indicated factors form of all the analyzed.

To the group of the most important barriers in realization of innovative goals among surveyed enterprises which were innovative active of the food industry, should also be included the high costs of such activity. Jasiński (2006) indicates that the high cost of innovative activity results from the expenditure on implementation and the high purchase price of modern scientific and technical solutions. It is worth to mention also that the relative low coefficient of variability (on the level of $32,1 \%$ ) and short interquartile range indicate compliance of respondents in the evaluation of the meaning of this factor in various countries of EU (Figure 1). Relatively the highest costs were indicated by those surveyed from Croatia - 49,6\%, Cyprus - 47,8\%, Latvia $38,8 \%$, Slovenia $-35,2 \%$ and Greece - 33,6\%. It was the main factor hindering the innovative activity within 5 from the 15 surveyed countries which are: Bulgaria, Germany, Estonia, Latvia and Poland.

The important impediment which accompanied the whole process of creation of innovative solutions in the food industry of analyzed countries was the difficulty in gaining public grants or subsidies.
At the greatest extend the representants of enterprises of food industry from Croatia $-52,7 \%$, Greece $-41,5 \%$, Slovenia - 38,2\%, Cyprus - 36\% and Bulgaria $28,4 \%$. In Greece this was the most indicated factor of all analyzed. Haffer and Haffer (2008) emphasize that greater access to external financing depends on appropriate formal facilities. Therefore, it is necessary to simplify the procedures for obtaining funding for an innovative purpose.

Of less importance in the realization of innovative activity was the uncertain market demand. A low coefficient of variation (on level $34,6 \%$ ) and a low range point out the relative compatibility of respondents in the evaluation of this factor in various countries of the EU. Most commonly, the uncertain demand of the market was pointed out by respondents from Slovenia and Italy, respectively $31,3 \%$ and $30,1 \%$ of those surveyed. In none of the analyzed countries was it the most important factor hampering the innovative activity in the food industry.

Implementation of innovations relates to running a research-development activity which requires high qualifications and competence of workers (Smit et al. 2015; Brown, Roper 2017). In most of the surveyed enterprises of the food industry it was not an important barrier. However, respondents relatively agreed as to the evaluation of this factor. It points out the low coefficient of variation (on the level $33,1 \%$ ). The highest percentage of enterprises of the food industry which were shown that the lack of enough qualifications of workers was an impediment in the introduction of innovations was noted in Hungary - 30,3\%, Croatia $-30,2 \%$ and Cyprus $-28,1 \%$.

Respondents relatively rarely pointed out the lack of possibility of external funding of innovative projects (credit or private capital). In none of analyzed countries was it the main factor impeding the innovative activities in the food industry. Most frequently respondents indicated a lack of external funding from the following countries: Croatia $37,4 \%$, Cyprus $-36,5 \%$ and Greece $-33,6 \%$. The least indicated factor which was hindering the innovative activity was the lack of partnership for cooperation. A relatively high percentage of enterprises indicating this factor was only in Croatia $-31,33 \%$. In the remaining of the analyzed countries it was not higher than $15 \%$. 


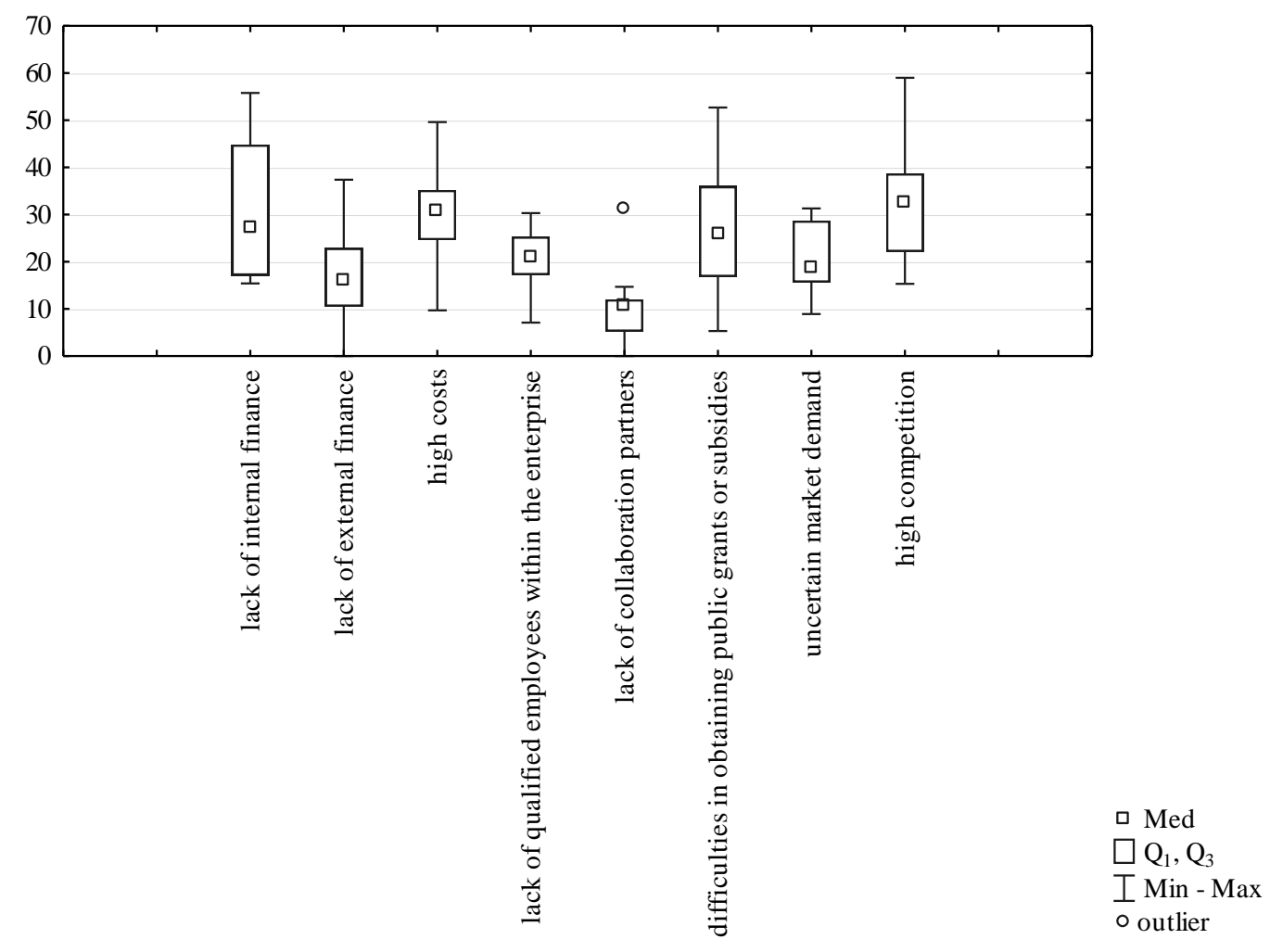

Figure 1. Box-plot figure for factors highly hampering innovation activity in innovation-active enterprises in the food industry in selected EU member states in the years 2014-2016 (\%)

Source: authors' calculations based on Eurostat, Community Innovation Survey (10.07.2019 r.)

Afterwards the chosen countries were grouped together because of the similarities of indications of factors which are highly impeding the innovative activity in innovative enterprises in the food industry in EU countries during 2014-2016. The effect of such a grouping was the creation of a hierarchical tree called dendrogram (Figure 2). Based on the analysis of the dendrogram three internal groups were identified in terms of evaluation of chosen barriers. The first cluster included: Bulgaria, Portugal, Hungary, Latvia and Slovakia. These were the countries with an average percentage of enterprises which perceived analyzed factors as the strong ones, impeding the innovative activity (Table 2). The following were recognized as the most important: lack of internal funding, high competition and high costs. The second group consists of Germany, Austria, Poland, Estonia, Italy and Malta. Countries of this concentration stood out on the low level among the other analyzed countries with a percentage of innovative enterprises of the food industry which evaluated chosen factors as highly important.
The biggest group of respondents of countries from this group (apart from Italy) recognized that high costs are important barriers. It is worth to mention that CIS-2016 research proved that Estonia, Italy and Germany were among countries which had biggest innovativeness of the food industry. More than a half of entities producing food within these countries (from $52,9 \%$ to $57,3 \%$ ) introduced during 2014-2016 innovations. Third class consisted of: Greece, Slovenia, Cyprus and Croatia. Countries of this focusing had a relatively big group of respondents (in comparison to the average) which perceived evaluated barriers as highly important in conducting innovative action. The most important barrier in countries of such class was lack of internal finance. 


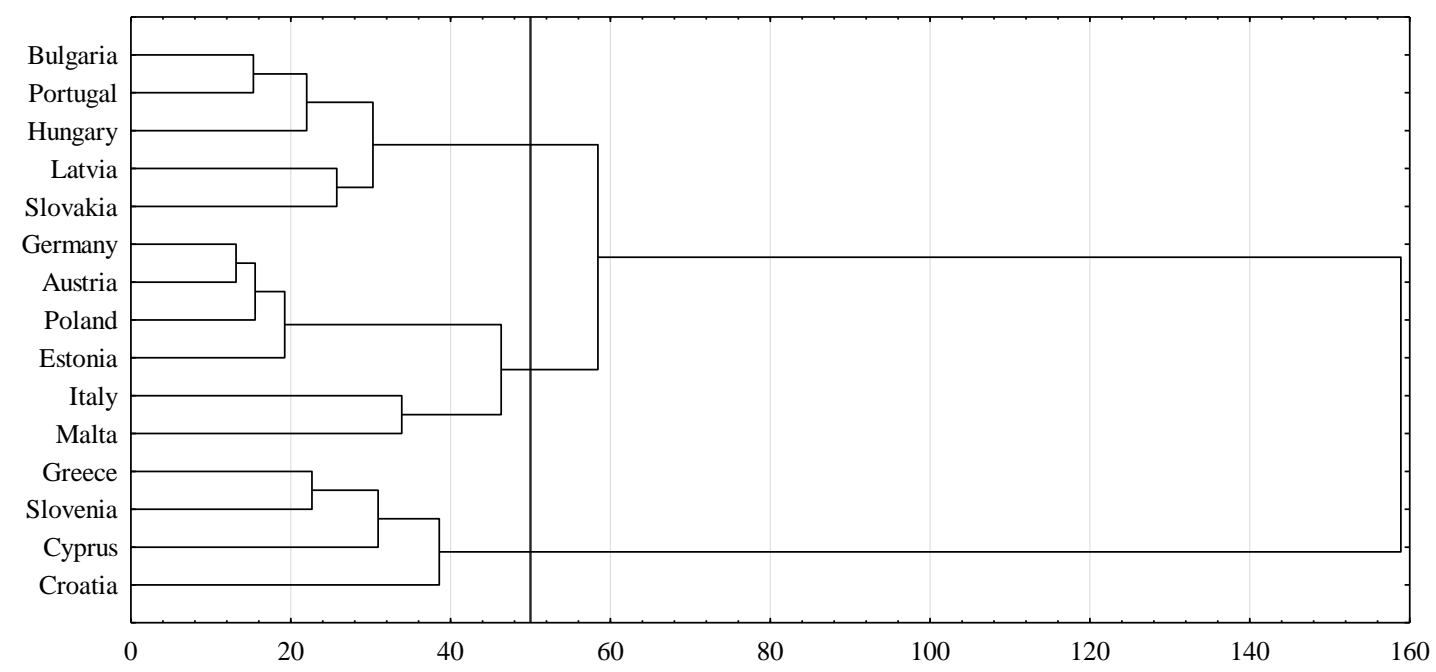

Figure 2. Typology of selected EU member states by factors highly hampering innovative activity in innovation-active enterprises in the food industry in 2012-2014

Source: authors' calculations based on Eurostat, Community Innovation Survey (10.07.2019)

Table 2. Typological classes of selected EU member states by factors highly hampering innovative activity in innovation-active enterprises in the food industry in 2012-2014

\begin{tabular}{|c|c|c|c|c|c|c|c|c|c|}
\hline \multirow[b]{2}{*}{$\begin{array}{l}\text { 음 } \\
\stackrel{0}{0}\end{array}$} & \multirow[b]{2}{*}{ Countries in group } & \multicolumn{8}{|c|}{ Average level (\%) } \\
\hline & & 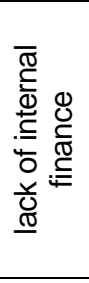 & 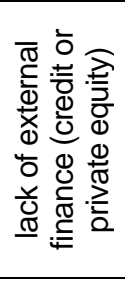 & 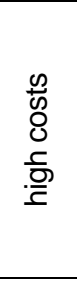 & 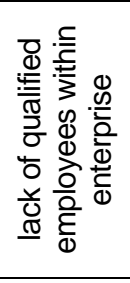 & 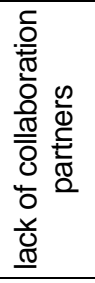 & 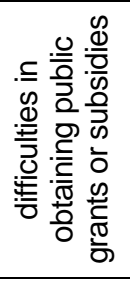 & 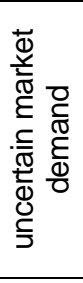 & 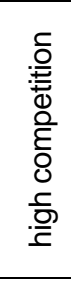 \\
\hline I & Bulgaria, Portugal, Hungary, Latvia, Slovakia & 32,5 & 15,6 & 31,2 & 19,1 & 9,9 & 26,7 & 18,8 & 31,5 \\
\hline II & Germany, Austria, Poland, Estonia, Italy, Malta & 19,5 & 10,7 & 23,5 & 17,9 & 6,0 & 14,4 & 18,5 & 24,9 \\
\hline III & Greece, Slovenia, Cyprus, Croatia & 48,6 & 32,6 & 41,6 & 26,5 & 17,0 & 42,1 & 27,4 & 43,3 \\
\hline & Altogether & 31,6 & 18,2 & 30,9 & 20,6 & 10,3 & 25,9 & 20,9 & 32,0 \\
\hline
\end{tabular}

Source: authors' calculations based on Eurostat, Community Innovation Survey (10.07.2019)

In another stage of research, barriers of innovative activity identified by representants of the food industry that did not carry out innovative activity in 2014-2016 were analyzed. The most important was the low demand on the market (Table 3). The highest median, arithmetic mean and high quartile (third) of distribution of responses within EU countries are pointing out this phenomenon (Figure 3 ). The biggest percentage of notification was noted in Cyprus and in Germany, accordingly $42,9 \%$ and $36,8 \%$ and then in Greece, Croatia and Slovakia (from $18,5 \%$ to $20,1 \%$ ). It was also the most commonly indicated barrier within 7 from 15 analyzed countries which are: Bulgaria, Germany, Greece, Croatia, Cyprus, Hungary and Austria.
The most often indicated highly important barriers preventing the introduction of something new in the food industry were also the financial barriers such as: lack of internal finance and high costs. Lack of internal finance is the obstacle indicated mostly by enterprises of the food industry in Slovakia - 24,3\%, and next in Greece - 18,3\%, Germany - 17,3\%, Italy - 14,4\% and in Portugal $13,4 \%$ and high costs by enterprises in Germany and Slovakia - $18,5 \%$. It is worth mentioning that in Slovakia and Portugal, lack of internal finance was the most important among all analyzed barriers in conducting innovative activity. 
Table 3. Highly significant barriers to innovative activity in non-innovative enterprises in the food industry in selected EU member states in 2014-2016 (\%)

\begin{tabular}{|c|c|c|c|c|c|c|c|c|c|c|c|c|}
\hline & 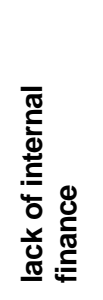 & 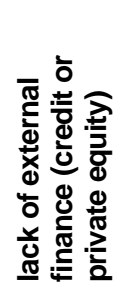 & $\begin{array}{l}\frac{0}{0} \\
0 \\
0 \\
\frac{5}{5} \\
\frac{0}{\varepsilon}\end{array}$ & 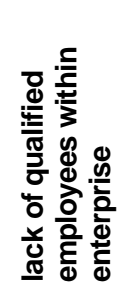 & 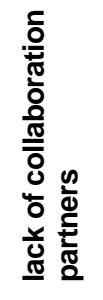 & 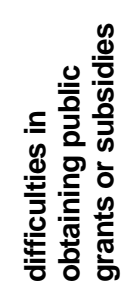 & 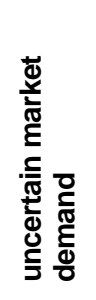 & 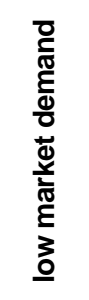 & 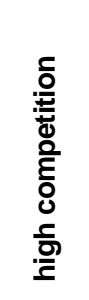 & 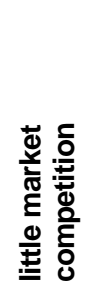 & 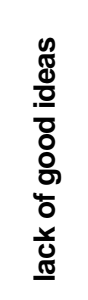 & 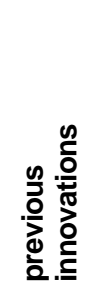 \\
\hline Bulgaria & 9,9 & 6,0 & 11,2 & 8,9 & 3,6 & 8,2 & 6,1 & 11,6 & 7,5 & 3,9 & 8,3 & 5,0 \\
\hline Germany & 17,3 & 9,1 & 18,5 & 8,8 & 6,0 & 7,4 & 8,2 & 36,8 & 19,3 & 7,7 & 4,0 & 13,8 \\
\hline Estonia & 5,6 & 9,7 & 9,7 & 9,7 & 2,8 & 13,9 & 4,2 & 15,3 & 19,4 & 4,2 & 11,1 & 11,1 \\
\hline Greece & 18,3 & 15,3 & 11,3 & 2,3 & 4,7 & 15,3 & 7,4 & 19,4 & 5,4 & 4,3 & 8,6 & 8,5 \\
\hline Croatia & 8,9 & 8,6 & 8,9 & 2,2 & 8,2 & 4,8 & 4,4 & 20,1 & 4,7 & 3,9 & 11,0 & 8,6 \\
\hline Italy & 14,4 & 11,0 & 10,0 & 20,6 & 10,3 & 9,8 & 13,2 & 12,8 & 19,2 & 2,9 & 2,4 & 11,4 \\
\hline Cyprus & 9,9 & 8,9 & 8,9 & 4,9 & 1,0 & 7,9 & 3,0 & 42,9 & 8,9 & 26,8 & 11,5 & 23,5 \\
\hline Latvia & 10,5 & 4,6 & 5,6 & 0,7 & 0,7 & 3,5 & 2,3 & 13,8 & 6,2 & 2,9 & 4,2 & 0,7 \\
\hline Hungary & 10,8 & 6,0 & 10,4 & 10,6 & 3,7 & 8,8 & 4,2 & 17,6 & 6,5 & 2,5 & 7,0 & 6,9 \\
\hline Malta & 6,9 & 6,9 & 10,3 & 3,4 & 3,4 & 6,9 & 3,4 & 10,3 & 3,4 & 0,0 & 0,0 & 3,4 \\
\hline Austria & 4,1 & 2,6 & 2,9 & 7,3 & 2,9 & 4,9 & 4,3 & 8,4 & 4,9 & - & - & - \\
\hline Poland & 9,1 & 6,4 & 10,0 & 6,4 & 4,3 & 7,6 & 6,1 & 6,9 & 8,0 & 4,3 & 7,7 & 5,7 \\
\hline Portugal & 13,4 & 12,7 & 9,6 & 4,6 & 5,3 & 7,7 & 6,3 & 11,2 & 8,7 & 2,2 & - & 9,2 \\
\hline Slovenia & 10,0 & 4,2 & 8,8 & 10,2 & 4,3 & 8,5 & 5,9 & 10,2 & 7,1 & 2,9 & 2,9 & 5,9 \\
\hline Slovakia & 24,3 & 12,7 & 18,5 & 8,5 & 3,9 & 18,9 & 11,2 & 18,5 & 13,9 & 3,9 & 12,0 & 10,0 \\
\hline arithmetic mean & 11,6 & 8,3 & 10,3 & 7,3 & 4,3 & 8,9 & 6,0 & 17,1 & 9,5 & 5,2 & 7,0 & 8,8 \\
\hline coefficient of variation (\%) & 45,5 & 42,8 & 38,5 & 66,9 & 56,8 & 46,3 & 50,1 & 59,5 & 58,7 & 124,6 & 56,5 & 61,6 \\
\hline
\end{tabular}

Source: authors' calculations based on Eurostat, Community Innovation Survey (10.07.2019)

Subsequently, respondents of CIS-2016 survey pointed the market aspect of introduction to innovations connected with high competition. Almost every fifth representative of non-innovative enterprises of the food industry in Estonia, Germany and Italy considered it a highly important barrier of introducing the innovations. In Estonia it was also the most important factor inhibiting innovative activity.

Results of the conducted research indicates that one barrier in introducing the innovations among non-innovative enterprises was the difficulty in gaining public grants and subsidies. It was felt mostly by representatives from the food industry in Slovakia - 18,9\%, Greece - 15,3\% and Estonia - 13,9\%. In other countries the percentage of answers pointed to the difficulty in gaining public grants or subsidies as highly relevant was not bigger than $10 \%$.

According to the respondents, factors causing abandonment of innovation introduction is also the implementation of past novelties. It was also indicated among others, on Cyprus, where $23,5 \%$ of the surveyed indicated that previous innovations are a highly important barrier for introduction of new ones. In Germany, Italy and Slovakia the percentage of indications on the level from $10 \%$ to $13,8 \%$ and in other countries from $0,7 \%$ to $9,2 \%$.

In further positions they came in the order: lack of internal finance, lack of qualified workers, lack of good ideas, uncertain market demand, little market competition and lack of collaboration partners. These were barriers of low importance in the creation of innovations in the opinion of representatives of noninnovative food industry enterprises. It is proven by arithmetic means of enterprise percentage which evaluated these factors as highly valued, emerging at a level of $4,3 \%$ to $8,3 \%$, as well with the median from $3,9 \%$ to $8,6 \%$ and third quartile from $4,3 \%$ to $11 \%$. 


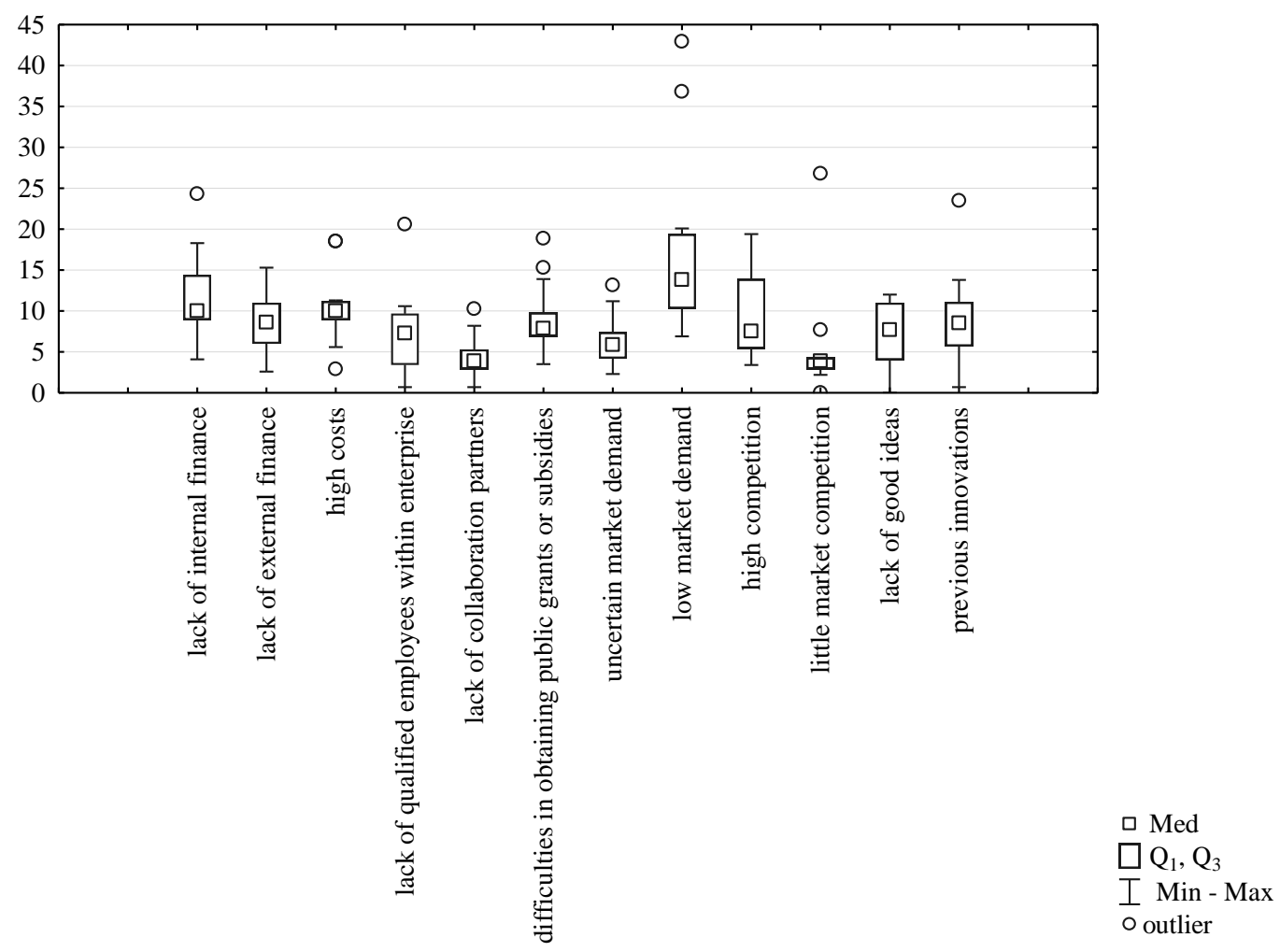

Figure 3. Box-plot figure of highly significant barriers to innovative activity in non-innovative enterprises in the food industry in selected EU member states in 2014-2016 (\%)

Source: authors' calculations based on Eurostat, Community Innovation Survey (10.07.2019)

Then, using the Ward' method, the analyzed EU member states were grouped due to the similarity of indications of barriers to innovative activity in the food industry inactive in innovation. Based on created dendrogram there were 3 groups of countries separated (Figure 4). To the most numerous firstclass, the following countries were classified: Bulgaria, Poland, Slovenia, Hungary, Croatia, Latvia and Malta (Table 4). These countries were characterized by a relative low percentage (compared to other groups) of enterprises which perceived analyzed factors as highly important barriers to innovativeness (apart from low demand, low competition and previous innovations). Conducted grouping also showed the similarities for compliance of perceiving the innovative barriers in non-innovative enterprises of the food industry between Estonia, Italy, Greece and Slovakia which created the second group. These were the countries which were characterized by a higher comparison then the average percentage of respondents, who evaluated chosen barriers as highly important in creation of innovations. In the third group, were Germany and Cyprus. These countries stood out mostly with the large group of enterprises in which it was considered that low demand on the market is a highly important barrier of innovativeness. The percentage of subjects which were paying attention to this was accordingly $36,8 \%$ and $42,9 \%$ while in the rest of the analyzed countries it was an average value of $17,1 \%$. Germany and Cyprus stood out also with a relatively regular indicator of little competition on the market and previous innovations as a barrier to the introduction of other novelties.

It is also worth paying attention to the issue of perception of innovation barriers by innovative and non-innovative enterprises. It is usually adopted that innovative barriers should be more important for the non-innovative enterprises. However, in the conducted analyzes, it turned out that barriers were more often indicated by the enterprises which were innovative active. As pointed out by Lewandowska (2014) such relations were also observed in other studies, for example those by Baldwin, Lin (2002) among the representative sample of Canadian production entrepreneurs and research by Mohnen and Rosa (2000) conducted within service entrepreneurs. Some of the research shows that perception of the importance of innovative barriers, has a significant impact on the ownership of company capital (foreign/external) (lammarino et al. 2009, za: Lewandowska, 2014). 


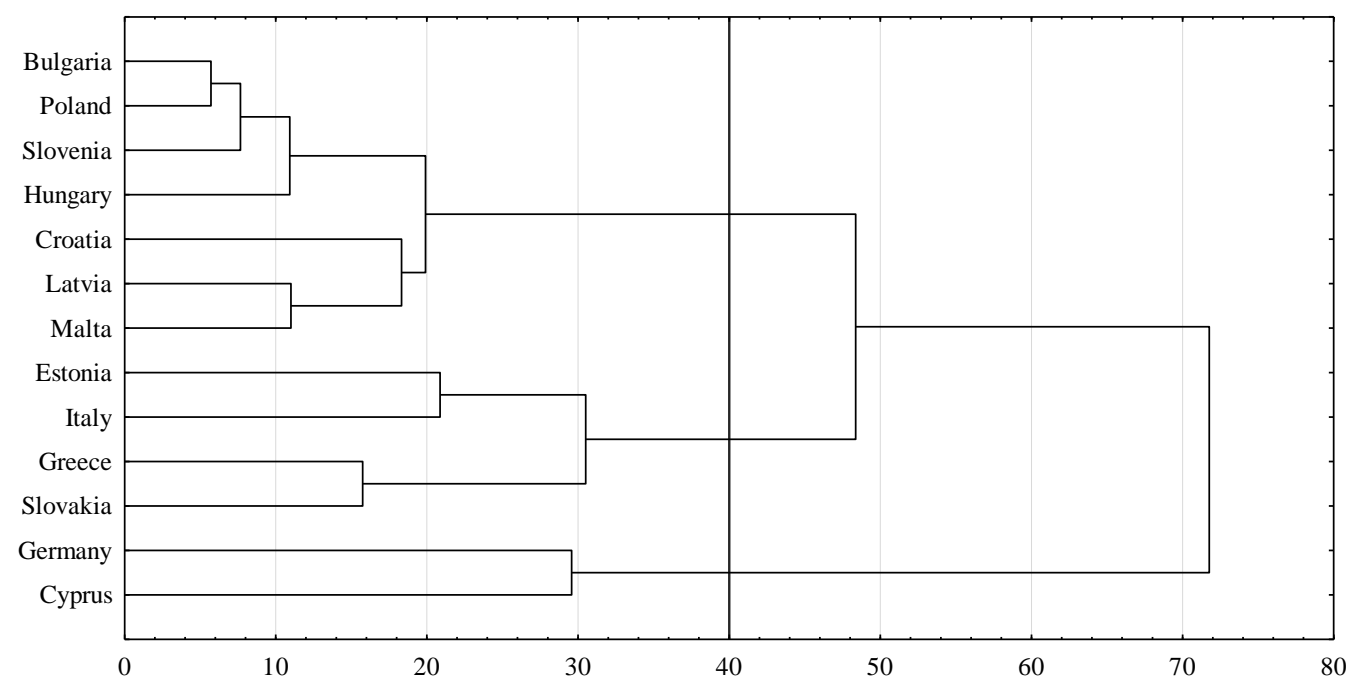

Figure 4. Typology of selected EU Member States according to innovation barriers in non-innovative enterprises in the food industry in 2012-2014

Source: authors' calculations based on Eurostat, Community Innovation Survey (10.07.2019)

Table 4. Typological classes of selected EU Member States by innovation barriers in non-innovative enterprises in the food industry in 2012-2014

\begin{tabular}{|c|c|c|c|c|c|c|c|c|c|c|c|c|c|}
\hline \multirow[b]{2}{*}{ Group } & \multirow[b]{2}{*}{$\begin{array}{l}\text { Countries } \\
\text { in group }\end{array}$} & \multicolumn{12}{|c|}{ Average level (\%) } \\
\hline & & 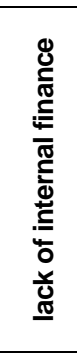 & 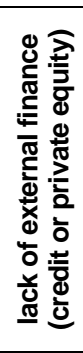 & $\begin{array}{l}\frac{0}{0} \\
0 \\
0 \\
\frac{1}{0} \\
\frac{0}{E}\end{array}$ & 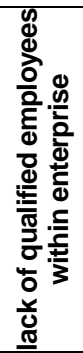 & 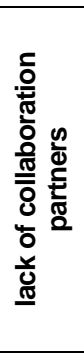 & 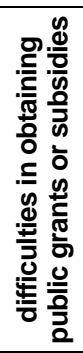 & 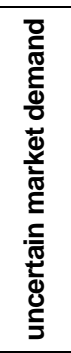 & 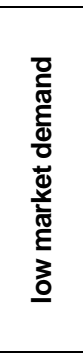 & 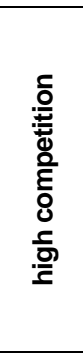 & 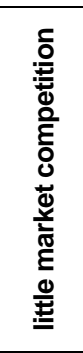 & 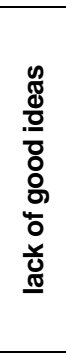 & 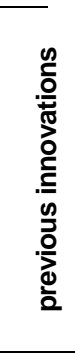 \\
\hline I & $\begin{array}{l}\text { Bulgaria, Poland, } \\
\text { Slovenia, Hungary, } \\
\text { Croatia, Latvia, Malta }\end{array}$ & 9,4 & 6,1 & 9,3 & 6,1 & 4,0 & 6,9 & 4,6 & 12,9 & 6,2 & 2,9 & 5,9 & 5,2 \\
\hline II & $\begin{array}{l}\text { Estonia, Italy, Greece, } \\
\text { Slovakia }\end{array}$ & 13,4 & 10,7 & 10,3 & 8,8 & 5,0 & 11,8 & 7,8 & 14,3 & 11,9 & 3,5 & 8,5 & 10,0 \\
\hline III & Germany, Cyprus & 13,6 & 9,0 & 13,7 & 6,9 & 3,5 & 7,7 & 5,6 & 39,9 & 14,1 & 17,3 & 7,8 & 18,7 \\
\hline & Altogether & 11,6 & 8,3 & 10,3 & 7,3 & 4,3 & 8,9 & 6,0 & 17,1 & 9,5 & 5,2 & 7,0 & 8,8 \\
\hline
\end{tabular}

\section{Conclusions}

In conditions of the modern market, the important factor of competitiveness of business entities is innovativeness. Increasing intra-industry competition, as well as gradual saturation of the food market and increasing consumer expectations mean that originality and the ability to stand out are becoming increasingly important in the food industry. However, entities which are going to implement some new solutions, often face some barriers.
Conducted analyzes show that:

- the main factors hampering the innovative activity in innovation-active enterprises of the food industry were: high competition and financial factors, including the lack of internal financing and high costs. The following were listed: difficulty in obtaining grants or subsidies and uncertain market demand;

- among the analyzed EU countries, innovation barriers were most often indicated by 
innovation-active food industry companies located in Greece, Slovenia, Cyprus and Croatia;

- there are differences in the perception of innovation barriers among innovation-active and non-innovative enterprises. In enterprises in which no innovation activity was conducted, the analyzed factors were less frequently assessed as highly significant innovation barriers;

- non-innovative enterprises most often indicated low market demand, lack of internal financing and high cost and then high competition;

- a relatively high percentage of non-innovative enterprises in the food industry, in which the analyzed factors were assessed as highly significant, was noted in Bulgaria, Poland, Slovenia, Hungary, Croatia, Latvia and Malta. Particular attention was paid to low demand, as well as low competition and previous innovations in Germany and Cyprus.

It needs to be highlighted that the problematics of identification and evaluation of innovativeness barriers of the food industry in the EU needs further monitoring. It would also be reasonable to conduct an in-depth qualitative research which may indicate the directions and means of overcoming the obstacles of innovation implementation in the food industry, and therefore improve its innovative and competitive potential.

\section{References}

Aghion, P., Bloom, N., Blundell, R., Griffith, R. and Howitt, P. (2005). Competition and innovation: an inverted-U relationship, Quarterly Journal of Economics 120, 701-728.

Baldwin, J., Lin Z. (2002). Impediments to advanced technology adoption for Canadian manufacturers. Research Policy 31(1), 1-18.

Brown, P. and Roper, S. (2017). Innovation and networks in New Zealand farming, Australian Journal of Agricultural and Resource Economics $61,422-442$.

Cetera W. (2010). Skazani na wyobraźnię. Warszawa: Promocja XXI.

Dolińska, M. (2010). Innowacje w gospodarce opartej na wiedzy. Warszawa: PWE,

Eurostat Statistical Data. (2019). http://ec.europa.eu/ eurostat/web/science-technology-innovation/ data/database.

Fortuin, F.T.J.M, Omta, S.W.F. (2009). Innovation drivers and barriers in food processing. British Food Journal 111(8), 839-851.
Gardijan, M., Lukač, Z. (2018), Measuring the relative efficiency of the food and drink industry in the chosen EU countries using the data envelopment analysis with missing data. Central European Journal of Operations Research, 26: 695-713. https://doi.org/10.1007/s10100-0180540-0.

Haffer, M., Haffer, R. (2008). Aktywność innowacyjna małych i średnich przedsiębiorstw Pomorza i Kujaw. Toruń: UMK.

Hatzichronoglou, T. (1997). Revision of the hightechnology sector and product classification. OECD Science, Technology and Industry Working Papers 02, doi: 10.1787/134337307632.

lammarino, S., Sanna-Randaccio, F., Savona, M. (2009). The perception of obstacles to innovation. Foreign multinationals and domestic firms in Italy. Revue d'Economie Industrielle 125, 75-104.

Jasiński, A.H. (2006). Innowacje i transfer techniki w procesie transformacji. Warszawa: Difin.

Kolarz, M. (2006). Wpływ zagranicznych inwestycji bezpośrednich na innowacyjność przedsiębiorstw w Polsce, Katowice: Wydawnictwo Uniwersytetu Śląskiego,.

Lewandowska, M.S. (2014). Innovation barriers and international competitiveness of enterprises from polish food processing industry. Research results. Oeconomia 13(4), 103-113.

Mancini, P., Marotta G., Nazzaro C., Simonetti, B. (2015). Consumer behaviour, obesity and social costs. The case of Italy. International Journal of Business and Society 16(2), 295-324.

Michalski, E. (2014). Czynniki determinujące innowacyjność przedsiębiorstwa. Handel wewnętrzny 6(353), 78-87.

Mohnen, P., Rosa, J. (2000). Les obstacles a l'innovation dans les industries de services au Canada. CIRANO Scientifi c Series. https://cirano.qc.ca/pdf/publication/2000s-14.pdf.

Oslo Manual, 2005. Guidelines for Collecting and Interpreting Innovation Data, OECD Publishing

Panek, T., Zwierzchowski, J. (2013). Statystyczne metody wielowymiarowej analizy porównawczej. Teoria i zastosowanie, Warszawa: Oficyna Wydawnicza.

Rudawska, J. (2017). Bariery działalności innowacyjnej w sektorze przedsiębiorstw. Studium przypadku. Quarterly Journal 1(20), 73-83.

Smit, M.J., Abreu, M.A. and de Groot, H.L.F. (2015). Micro-evidence on the determinants of innovation in the Netherlands: the relative importance of absorptive capacity and agglomeration externalities, Papers in Regional Science 94, 249-272.

Soriano, F.A., Villano R.A. Fleming U.M., Battese G.E. (2018). What's driving innovation in small businesses in Australia? The case of the food industry. Agricultural and Resources Economics 59, 1-33. 
Stanisz, A. (2006). Przystępny kurs statystyki z zastosowaniem STATISTICA

PL na przykładach z medycyny Tom 1. Statystyki podstawowe. Kraków: StatSoft Polska.

Strychalska-Rudzewicz, A. (2012). Kultura organizacyjna a innowacyjność przedsiębiorstwa: diagnoza kultury na przykładzie dwóch organizacji. Ekonomiczne Problemy Usług 90, 109-126.

Suchecki, B., Lewandowska-Gwarda, K. (2010). Ekonometria przestrzenna. Metody i modele analizy danych przestrzennych, Warszawa: C.H. Beck.
Szopik-Depczyńska, K. (2009). Klasyfikacja czynników aktywności innowacyjnej przedsiębiorstw. Nierówności Społeczne a Wzrost Gospodarczy 15, 94-104.

Toth, J., Ferto, M. (2017). Innovation in the Hungarian food economy, Agric. Econ.- Czech 63(1), 43-51.

Wilson, S. (2018), Assessing export competitiveness of food manufacturers in SIDS, Competitiveness Review: An International Business Journal 28(4): 408-432. https://doi.org/10.1108/CR-07-20160038 . 